\title{
EDUKASI PENERAPAN PROTOKOL KESEHATAN SEBAGAI UPAYA PENCEGAHAN PENYEBARAN COVID-19 PADA PENDERITA KOMORBID
}

\author{
Julvainda Eka P.U ${ }^{1 *}$, Wilda Fauzia ${ }^{2}$, M.Jamaluddin ${ }^{3}$ \\ ${ }^{1}$ Stikes Karya Husada Semarang \\ ${ }^{2}$ Stikes Karya Husada Semarang \\ ${ }^{3}$ Stikes Karya Husada Semarang

\section{Abstract}

Corresponding author: Julvainda Eka P.U

Stikes Karya Husada Semarang

Email: julvaindaeka@gmail.com

\section{Article Info:}

Dikirim: 4 Maret 2021

Ditinjau: 5 Maret 2021

Diterima: 7 April 2021

DOI:

https://doi.org/10.33475/jikmh.diisiredaksi
Background: Corona virus disease-19 or Covid-19 is a disease that can be spread by humans to humans through droplets such as coughing or sneezing, although the specific transmission pattern is still not known with certainty. Spread can cause more severity in people with comorbid diseases. Prevention of spread can be done by implementing health protocols and increasing body immunity through education. Research Objectives: This study aims to identify the effect of providing Health Protocol Implementation Education as an Effort to Prevent the Spread of Covid-19 in comorbid sufferers in the Semarang City Health Center Work Area. Methods: This research method is a quantitative study using a quasi-experimental design with a one group pretest posttest design approach. The sample in this study was 48 respondents with comorbid patients who were taken by consecutive sampling technique. Research data collection using google forms questionnaire. Data were analyzed using descriptive statistics and Wilcoxon test. Results: The results showed that there was an effect of education on knowledge of the spread of Covid-19 ( $p=0.00$ $<0.03)$. Conclusion: Based on the results of the study, it can be concluded that education plays an important role in preventing the spread of Covid-19

Keywords: Covid-19; Education; Health Protocols.

\begin{abstract}
Abstrak
Latar Belakang : Corona virus disease-19 atau Covid-19 merupakan penyakit yang dapat disebarkan manusia ke manusia melalui droplet seperti batuk atau bersin, walaupun pola transmisi secara spesifik masih belum diketahui secara pasti. Penyebaran dapat menyebabkan keparahan semakin berat pada penderita penyakit komorbid. Pencegahan penyebaran dapat dilakukan dengan menerapkan protokol kesehatan dan meningkatkan imunitas tubuh melalui edukasi. Tujuan Penelitian : Penelitian ini bertujuan untuk mengidentifikasi pengaruh pemberian Edukasi Penerapan Protokol Kesehatan sebagai Upaya Pencegahan Penyebaran Covid-19 pada penderita komorbid di Wilayah Kerja Puskesmas Kota Semarang. Metode Penelitian : Metode penelitian ini adalah penelitian kuantitatif menggunakan desain quasi experiment dengan pendekatan one group pretest posttest design. Sampel dalam penelitian ini adalah 48 responden penderita komorbid yang diambil dengan teknik consecutive sampling. Pengumpulan data penelitian menggunakan kuesioner google forms. Data dianalisis menggunakan statistik deskriptif dan Wilcoxon test. Hasil : Hasil penelitian menunjukkan bahwa ada pengaruh edukasi terhadap pengetahuan penyebaran Covid-19 ( $\mathrm{p}=0,00<0,03)$. Kesimpulan : Berdasarkan hasil penelitian dapat disimpulkan bahwa edukasi berperan penting dalam pencegahan penyebaran Covid-19.
\end{abstract}

Kata Kunci: Covid-19; Edukasi; Protokol Kesehatan 


\section{PENDAHULUAN}

Novel coronavirus disease 2019 atau yang kemudian disebut Covid-19 yang sebelumnya diketahui pada sekitar Desember 2020 di Wuhan China saat ini menjadi pandemik global (WHO, 2020). Kasus pertama Covid-19 di Indonesia ditemukan pada 2 Maret 2020 yang saat itu berjumlah 2 kasus. Angka kasus terkonfirmasi positif Covid19 semakin hari semakin meningkat tajam baik secara nasional ataupun global. Jumlah postif Covid-19 global sebanyak 116.048 kasus. Jumlah kasus Nasional tanggal 5 Juni 2020, Kasus terkonfirmasi positif sebanyak 25.521 Orang (Satgas Covid 19, 2020). Kasus di Jawa Tengah sebanyak 1.591 Kasus. Berdasarkan pola transmisi, hampir semua wilayah melaporkan kasus ini sehingga pemerintah membuat peta penyebaran dan kategori zona penyebaran. Wilayah jawa tengah sendiri merupakan wilayah dengan kategori zona merah dengan kasus terbanyak (Satgas Covid 19, 2020).

Berdasarkan bukti gejala yang muncul di bagian zona merah nasional termasuk diantaranya jawa tengah, menunjukkan gejala, demam, batuk, sesak napas, lemas, mual, pilek, sakit tenggorokan dan sakit kepala. Dari segi riwayat penyakit penyerta didapatkan penyakit kronis yang menjadi salah satu faktor yang memperparah kondisi pasien positif seperti; riwayat Diabetes Mellitus, Hipertensi, Gagal Jantung, Ginjal Kronis, Stroke dan Jantung Koroner (Satgas Covid 19, 2020). Berdasarkan hasil penelitian Huang (2020) sebanyak 41 pasien yang di rawat karena Covid-19 di Wuhan, Cina memiliki riwayat penyakit Diabetes Melitus, Hipertensi, dan Penyakit Kardiovaskuler dengan gejala umum yang ditemukan demam, batuk, myalgia atau kelelahan dan gejala tidak umum terdapat sputum, sakit kepala, hemoptisis, diare dan sesak napas.

Faktor resiko terinfeksi Covid-19 juga perlu di waspadai terutama pada penderita Hipertensi dan Diabetes Melitus (Fang Et al, 2020). Kondisi tubuh pasien yang terinfeksi dapat menjadi lebih berat pada Hipertensi dan Diabetes Melitus. Kaitan faktor lain juga beresiko pada perokok aktif. Faktor usia yang paling banyak terinfeksi pada rentang 30-79 tahun sebanyak 87\% kasus di bandingkan dibawah 30 tahun (Cai, 2020). Ini menunjukkan tidak ada batasan usia dalam penyebaran infeksi tetapi pada usia rentan harus di waspadai.

Pola transmisi dan gejala yang dilaporkan pada masingmasing kasus berbeda-beda. Bukti adanya Penyebaran dari droplet dan melalui benda mati juga di laporkan dapat menyebarkan Covid-19. Hal ini menunjukkan kewaspadaan personal terhadap kebersihan dan penggunaan alat pelindung diri sangat penting diterapkan kepada masyarakat secara luas (WHO, 2020). Gejala dan keluhan pasien terkonfirmasi positif Covid-19 menunjukkan gejala yang berbeda-beda, mulai dari tanpa gejala, gejala ringan sampai gejala berat (Cai, 2020). Berdasarkan hal tersebut, dapat menimbulkan kekhawatiran pada masyarakat bahwa seseorang membawa Covid-19 atau tidak dalam tubuhnya ketika tidak menunjukkan gejala.

Tidak dapat dipungkiri bahwa penyebaran virus ini sangat cepat di masyarakat karena mobilitas yang sangat tinggi ke wilayah pandemi. Sehingga tidak dapat dikendalikan secara per orangan mengingat penyebarannya tidak pandang status usia dan jenis kelamin. Oleh karena itu kelompok rentan di masyarakat seperti anak-anak, lansia dan kelompok masyarakat dengan komorbid penyakit kronis harus terlindungi dengan baik. Dalam pedoman protokol kesehatan yang dikeluarkan oleh Kemenkes RI (2020) maupun Satgas Covid-19 (2020) telah di sebutkan bahwa kelompok rentan tersebut secara khusus dan masyarakat secara umum tidak dianjurkan untuk melakukan aktivitas yang tidak perlu di luar rumah. Selain itu, apabila tidak terlalu gawat untuk tidak pergi ke pelayanan kesehatan. Hal ini dikarenakan pelayanan kesehatan saat ini bukan merupakan tempat yang aman untuk dikunjungi.

Banyak gejala yang muncul dari pasien yang diindikasi terkena virus covid-19, namun belum seluruhnya diketahui bagaimana pola transmisinya. Hingga saat ini observasi dan penelitian pola virus masih terus di lakukan sehingga himbauan dari WHO maupun Satgas Covid-19 
untuk menerapkan protokol kesehatan dan menjaga imunitas diyakini mampu mencegah penyebaran lebih luas untuk saat ini sampai ditemukan obat ataupun vaksin yang tepat. Penerapan perilaku ini membutuhkan himbauan secara berulang karena merupakan kebiasaan baru yang harus di terapkan sehari-hari oleh masyarakat tanpa terkecuali. Oleh karena itu perlu dilakukan edukasi tentang pentingnya menerapkan protokol kesehatan dan menjaga imunitas tubuh dengan tepat dan baik.

\section{METODE}

Metode penelitian ini adalah penelitian kuantitatif menggunakan desain quasi experiment dengan pendekatan one group pretest posttest design. Sampel dalam penelitian ini adalah 48 responden penderita komorbid yang diambil dengan teknik consecutive sampling. Kriteria inklusi sampel adalah responden yang mengalami keluhan atau gejala penyakit komorbid saat penelitian. Sebelum dan sesudah diberikan edukasi, responden di berikan kuesioner tertutup tentang Covid-19 sebanyak 110 item pertanyaan. Responden yang telah memenuhi syarat penelitian diberikan kuesioner untuk di isi dan dikirimkan melalui google form. Setelah responden mengumpulkan kuesioner, kemudian dilanjutkan dengan pemberian materi edukasi secara virtual melalui aplikasi Zoom. Setelah edukasi selesai diberikan, responden kembali di bagikan kuesioner evaluasi untuk diisi dan dikumpulkan kembali. Pengumpulan data penelitian menggunakan kuesioner google forms yang berisi tentang Covid-19, Transmisi dan Cara Pencegahan (WHO, 2020; Satgas Covid-19, 2020). Data dianalisis menggunakan statistik deskriptif dan Wilcoxon test. Penelitian ini telah mendapat ijin dari dan persetujuan dari STIKes Karya $\mathrm{Hu}-$ sada Semarang dan izin resmi dari wilayah setempat. Persetujuan penelitian diberikan kepada responden yang berpartisipasi setelah menjelaskan tujuan dan prosedur penelitian. Peneliti menjamin anonimitas subjek dan kerahasiaan data, dan kebebasan untuk keluar dari penelitian kapan saja tanpa ada paksaan.

\section{HASIL DAN PEMBAHASAN}

Banyak faktor yang mempengaruhi dalam upaya peningkatan kesehatan seseorang. Faktor-faktor tersebut dapat menjadi suatu dasar dalam menentukan strategi dalam pemberian edukasi kesehatan. Dalam penelitian ini menunjukkan karakteristik responden berpengaruh terhadap penerimaan edukasi yang disampaikan. Edukasi yang disampaikan dengan baik akan berdampak kepada persepsi kognitif seseorang dalam melihat pentingnya kesehatan. Pada akhirnya mereka kemudian akan meyakini dan menyadari bahwa kesehatan merupakan suatu kebutuhan personal setiap orang. Hal ini dapat mendorong responden secara kognitif mudah menangkap apa yang di sampaikan dari edukator yang kemudian menerima dan melakukan cara-cara yang di berikan untuk meningkatkan kesehatan serta mencegah suatu penyakit yang berdampak pada kesehatan (Smeltzer dan Bare, 2010).

Tabel 1. Karakteristik Responden

\begin{tabular}{lcc}
\hline \multicolumn{1}{c}{ Variabel } & $\begin{array}{c}\text { Jumlah } \\
\text { (n) }\end{array}$ & $\begin{array}{c}\text { Prosentase } \\
\text { (\%) }\end{array}$ \\
\hline Jenis Kelamin & & \\
Laki-laki & 8 & 16,3 \\
Perempuan & 40 & 83,7 \\
Usia & & \\
26-35 Tahun & 2 & 4,2 \\
36-45 Tahun & 15 & 31,2 \\
46-55 Tahun & 17 & 35,4 \\
56-65 Tahun & 14 & 29,2 \\
Riwayat Penyakit & & \\
Gg. Autoimun & 5 & 10,4 \\
Hipertensi & 21 & 43,8 \\
Diabetes & 16 & 33,3 \\
Asma & 6 & 12,5 \\
Sumber Informasi & & \\
Televisi & 28 & 58,3 \\
Media & 17 & 35,4 \\
Koran & 3 & 6,2 \\
\hline
\end{tabular}

Berdasarkan Tabel 1 Diketahui mayoritas responden berjenis kelamin perempuan sebanyak 40 orang $(83,7 \%)$, responden dari segi usia mayoritas lansia awal (46-55 Tahun) sebanyak 17 orang $(35,4 \%)$, responden dengan riwayat penyakit terakhir mayoritas Hipertensi sebanyak 
sebanyak 21 orang $(43,8 \%)$, sumber informasi yang di dapat responden mayoritas dari televisi sebanyak 28 $(58,3 \%)$.

Banyak faktor yang mempengaruhi dalam upaya peningkatan kesehatan seseorang. Faktor-faktor tersebut dapat menjadi suatu dasar dalam menentukan strategi dalam pemberian edukasi kesehatan. Dalam penelitian ini menunjukkan karakteristik responden berpengaruh terhadap penerimaan edukasi yang disampaikan. Edukasi yang disampaikan dengan baik akan berdampak kepada persepsi kognitif seseorang dalam melihat pentingnya kesehatan. Pada akhirnya mereka kemudian akan meyakini dan menyadari bahwa kesehatan merupakan suatu kebutuhan personal setiap orang. Hal ini dapat mendorong responden secara kognitif mudah menangkap apa yang di sampaikan dari edukator yang kemudian menerima dan melakukan cara-cara yang di berikan untuk meningkatkan kesehatan serta mencegah suatu penyakit yang berdampak pada kesehatan (Smeltzer dan Bare, 2010).

Persepsi dan penerimaan kognitif dari edukasi tentang penyakit Coronavirus (COVID-19) pada responden juga dapat di latar belakangi oleh riwayat penyakit yang sedang di derita seperti. Penyakit komorbid atau penyakit kronis sangat rentan terhadap infeksi Covid-19 karena proses penyakit yang sedang berlangsung dapat menurunkan kekebalan tubuh penderita. Infeksi Covid-19 dapat menyebabkan gangguan pada fungsi fisiologis pada pasien dengan gangguan Jantung (Herick, Ketaren, Supit, 2020). Hal ini menjadi pendorong penderita komorbid untuk mematuhi protokol kesehatan yang di sampaikan untuk mencegah penyebaran Covid-19. Karena penyakit coronavirus merupakan penyakit menular yang baru di temukan, ini juga mendorong responden mendengar dengan baik tentang informasi baru yang mereka terima (WHO, 2020, Younie S, Mitchell C, Bisson MJ, Crosby S, Kukona A, et al. 2020 ; Smeltzer dan Bre, 2010).

Di samping itu, kematangan usia juga membantu responden mampu menangkap pesan sesuai tujuan dan sasaran edukasi karena berhubungan dengan faktor-faktor yang dapat mencegah penyakit dan meningkatkan derajat kesehatan. Dalam penelitian ini, mayoritas responden memasuki usia lansia awal dan akhir yang merupakan usia yang sudah matang dalam menangkap pesan yang informatif dan berguna bagi kesehatan mereka (Chen, 2020).

Tabel 2 Pengaruh Edukasi terhadap Pengetahuan Tentang Covid19 Sebelum dan Sesudah Intervensi

\begin{tabular}{cccc}
\hline \multirow{2}{*}{$\begin{array}{c}\text { Pengetahuan } \\
\text { Covid-19 }\end{array}$} & \multicolumn{2}{c}{ Mean } & \multirow{2}{*}{ Nilai $\boldsymbol{p}$} \\
\cline { 2 - 3 } & Pre & Post & \\
\cline { 2 - 3 } & 16,5 & 16,75 & 0,003 \\
\hline
\end{tabular}

Berdasarkan Tabel 2 diketahui rerata nilai pengetahuan sebelum dan sesudah intervensi. Terdapat peningkatan sebesar 0,25 setelah mendapatkan edukasi. Nilai statistik menunjukkan nilai $p 0,003<0.05$ dari derajat kemaknaan. Hal ini menunjukkan terdapat Pengaruh pemberian edukasi terhadap tingkat pengetahuan responden terhadap pencegahan Covid-19.

Peningkatan tersebut tidak terlalu optimal, dimungkinkan karena mayoritas responden memasuki usia lansia awal, yang mana pada usia tersebut terjadi penurunan fungsi analisis maupun daya ingat terhadap informasi baru. Fungsi analisis dan daya ingat ini juga dapat di karenakan faktor penyakit yang sedang di derita. Namun dilihat secara keseluruhan, dapat di simpulkan edukasi mempengaruhi peningkatan pengetahuan responden secara umum (Younie S, Et al. 2020).

Edukasi merupakan upaya yang direncanakan untuk mempengaruhi orang lain baik individu, kelompok atau masyarakat sehingga mereka melakukan apa yang diharapkan oleh pelaku pendidikan. Media penyampaian edukasi bermacam-macam, dapat menggunakan media visual seperti media cetak (booklet, leaflet, flipchart, poster dan tulisan), media elektronik (televisi dan slide) dan media papan atau billboard (Notoadmodjo, 2012). Namun setelah muncul Covid-19 yang kemudian menyebabkan pandemik global, strategi pemberian edukasi mengalami pergeseran dalam hal penyampaian dan metode edukasi. Berbagai metode dikembangkan melalui platform yang 
memungkinkan edukasi tetap dapat disampaikan walaupun melalui tatap muka secara on line contohnya Zoom yang dipakai selama penelitian (UNESCO, 2020 ; Han, Yang, 2020 ; Abidah, Hidayatullah, Simamora, Fehabutar , Mutakin, 2020).

Perubahan strategi dan metode edukasi di karenakan kebijakan penanganan Covid-19 dalam pencegahan transmisi di masyarakat untuk menjaga jarak secara fisik dan sosial serta karantina mandiri di rumah (Kemenkes RI dan Satgas Covid-19, 2020). Kondisi ini tidak memungkinkan edukasi kesehatan dapat diterapkan seperti sebelum Covid-19 terjadi. Penderita komorbid tidak di anjurkan untuk keluar rumah apalagi ke pelayanan kesehatan yang masih belum dikatakan aman bagi usia lansia jika tidak dalam kondisi darurat meski tingkat kepatuhan cuci tangan tinggi pada tenaga kesehatan selama pandemik (Moore, 2020). Sejak kasus positif Covid-19 meningkat, banyak tempat pelayanan kesehatan membatasi kunjungan dan pelayanan rawat jalan. Sehingga penderita komorbid juga tidak dapat memantau perkembangan penyakitnya secara rutin (Younie S, Et al. 2020).

Upaya peningkatan kesehatan tidak terlepas dari peran edukasi tentang kesehatan itu sendiri. Melalui edukasi, informasi dapat disampaikan untuk memberikan gambaran kesehatan, dampak suatu penyebab gangguan kesehatan dan cara-cara preventif untuk meningkatkan kesehatan. Penderita penyakit kronis memiliki pengalaman tentang keluhan, gejala dan kebiasaan yang berpengaruh terhadap penyakitnya. Hal ini dapat mendorong untuk mengubah gaya hidup, perilaku dan lingkungan yang dapat beresiko mempengaruhi kualitas hidup seseorang (Whitehead, 2004 ; Smeltzer \& Bre, 2010 ; Alwehedy, Elhameed \& Elhameed, 2014).

Edukasi pada pasien merupakan proses interaksi antara perawat dan pasien serta perawat dan keluarga, memberikan informasi kesehatan serta menambah pengetahuan pasien dan keluarga sehingga dapat menciptakan pelayanan praktik keperawatan yang efektif dan efisien (Potter \& Perry, 2010). Penelitian ini menunjukkan peran serta dukungan keluarga sangat membantu responden selama edukasi dan penelitian berlangsung. Interaksi oleh edukator dapat berlangsung dengan baik walaupun dilakukan secara virtual karena keluarga membantu responden menyiapkan media dan alat komunikasi yang dibutuhkan selama edukasi secara daring. Hal ini tidak mengurangi esensi edukasi yang di berikan peneliti.

Faktor yang berperan dalam peningkatan kesehatan untuk meningkatkan kualitas hidup di jelaskan oleh Becker et al. (1974) dalam 4 variabel. Pertama, faktor demografi dan penyakit seperti usia, jenis kelamin, tingkat pendidikan, pekerjaan, tingkat keparahan penyakit dan lama sakit. Kedua, faktor hambatan dalam kemudahan dan kesulitan mendapatkan akses kesehatan. Ketiga, sumber-sumber mendapatkan kesehatan seperti finansial dan dukungan sosial. Keempat, faktor persepsi seseorang memandang status kesehatannya, self-efficacy dan tuntutan dari penyakitnya. Dalam penelitian ini, dapat dilihat bahwa faktor kematangan usia, pola pikir berdasarkan gender, riwayat penyakit yang diderita dan wawasan pengetahuan yang didapatkan melalui pendidikan dan sumber informasi yang diperoleh dari media elektronik dan digital tentang Covid19 menambah kemudahan edukasi dalam meningkatkan pengetahuan tentang pencegahan Covid-19 (Younie, 2020).

Edukasi dapat mendorong peningkatan kesehatan responden dalam mencegah penyebaran virus dikalangan penderita komorbid walaupun edukasi sangat berbeda dengan promosi kesehatan itu sendiri. Kegiatan edukasi sendiri lebih berfokus pada pemberian pengetahuan melalui interaksi dengan penderita atau pasien. Sedangkan promosi kesehatan berfokus pada cara-cara dalam meningkatkan perilaku promosi kesehatan (Whitehead, 2010). Namun melalui edukasi tentang pencegahan penyebaran Covid-19 diharapkan akan mengubah persepsi responden untuk melakukan kegiatan yang mencegah penyebaran.

Pencegahan penyebaran virus itu sendiri sudah di rumuskan oleh Kemenkes RI dan Satgas Covid-19 (2020) dalam 
pedoman Protokol Kesehatan. Dalam pedoman tersebut terdapat beberapa poin guna pengendalian dan pencegahan penyebaran diantaranya melalui kegiatan edukasi tentang mencuci tangan pakai sabun atau handsanitizer, pengaturan jaga jarak, disinfeksi terhadap permukaan, ruangan, dan peralatan secara berkala, serta penegakkan kedisplinan pada perilaku masyarakat yang berisiko dalam penularan dan tertularnya COVID-19 seperti berkerumun, tidak menggunakan masker, merokok di tempat dan fasilitas umum dan lain sebagainya. Kebijakan ini perlu di terapkan mengingat media digital beresiko menyebarkan informasi yang tidak tepat tentang Covid-19 dan penyebarannya (Purnama, 2020).

\section{KESIMPULAN}

Hasil penelitian menunjukkan tingginya pengetahuan baik sebelum dan sesudah diberikan edukasi disebabkan oleh faktor usia, jenis kelamin, riwayat penyakit dan sumber informasi tentang Covid-19 dan pencegahannya melalui media elektronik maupun digital. Selain itu, sosialisasi oleh pemerintah setempat untuk melaksanakan dan mematuhi protokol kesehatan melalui kebijakan yang berlaku juga membantu meningkatkan pengetahuan responden tentang pentingnya mematuhi protokol kesehatan.

Berdasarkan hasil penelitian dapat disimpulkan ada pengaruh pemberian Edukasi Penerapan Protokol Kesehatan sebagai Upaya Pencegahan Penyebaran Covid19 pada penderita komorbid di Wilayah Kerja Puskesmas Kota Semarang. Dengan demikian edukasi tentang Covid19 sangat mendukung penerapan protokol kesehatan pada masyarakat.

\section{UCAPAN TERIMA KASIH}

Ucapan Terima Kasih Kami Ucapkan kepada Masyarakat di Wilayah Kerja Puskesmas Kota Semarang atas partisipasi dan waktu yang telah di sempatkan dalam penelitian ini.

\section{DAFTAR RUJUKAN}

Abidah A, Hidayatullah HN, Simamora RM, Fehabutar D, Mutakin L. (2020). The Impact of Covid-19 to Indonesian Education and Its Relation to the Philosophy of "Merdeka Belajar". Journal homepage: http://scie-journal.com/index.php/SiPoSE. Studies in Philosophy of Science and Education (SiPoSE) Vol.1, No.1, April 2020, pp. 38-49 ISSN: 27219267

Alwehedy, A., Elhameed, S. H. A \& Elhameed, D.A. (2014). Effect of lifestyle intervention program on controlling among older adults. Journal of Education and Practice, 5(5), 61-71. ISSN 2222-288x. Diakses dari http://www.iiste.org.

Cai H. Sex difference and smoking predisposition in patients with COVID-19. Lancet Respir Med. 2020; published online March 11. DOI: 10.1016/S22132600(20)30117-X

CDC. (2020). Symtoms Corona virus.

https://www.cdc.gov/coronavirus/2019ncov/symptoms-testing/symptoms.html

Chen X, Ran L, Liu Q, Hu Q, Du X, Tan X. (2020). Hand Hygiene, Mask-Wearing Behaviors and Its Associated Factors during the COVID-19 Epidemic: A CrossSectional Study among Primary School Students in Wuhan, China. Int. J. Environ. Res. Public Health 2020, 17, 2893; doi:10.3390/ijerph17082893.

www.mdpi.com/journal/ijerph

Fang L, Karakiulakis G, Roth M. (2020) Are patients with hypertension and diabetes mellitus at increased risk for COVID-19 infection? Lancet Respir Med. 2020; published online March 11. DOI: 10.1016/S22132600(20)30116-8.

Han Y, Yang H. The transmission and diagnosis of 2019 novel coronavirus infection disease (COVID-19): A Chinese perspective. J Med Virol. 2020; published online March 6. DOI: 10.1002/ jmv.25749 
Hastjarjo. (2018). Quast-Eksperimentation : Design \& Analisis Issues For Field Setting. Boston : Houghton Mifflin Company.

Herick WA, Ketaren, I, Supit, IAI. (2020). Dampak Coronavirus Disease 2019 terhadap Sistem Kardiovaskular. e-CliniC. 2020;8(2):237-245

DOI: https://doi.org/10.35790/ecl.8.2.2020.30540. eISSN 2337-5949. https://ejournal.unsrat.ac.id/ind ex.php/eclinic

Huang, C. et al. (2020). Clinical features of patients infected with 2019 novel coronavirus in Wuhan, Chi$n a$.

https://www.thelancet.com/journals/lancet/article/PI IS0140-6736(20)30183 5/fulltext

\section{Kemenkes RI.}

https://covid19.kemkes.go.id/protokol-covid19/protokol-kesehatan-bagi-masyarakat-di-tempatdan-fasilitas-umum-dalam-rangka-pencegahancovid-19/\#.X40R2tUzbIU

Moore LD, Robbins GBA, Quinn J, Arbogast JW. (2020). The impact of COVID-19 pandemic on hand hygiene performance in hospitals. American Journal of Infection Control 49 (2021) 30-33. https://doi.org/10.1016/j.ajic.2020.08.021. www.ajicjournal.org

Notoatmodjo, S. (2012). Metode Penelitian Kesehatan. Jakarta : PT Rineka Cipta.

Notoatmodjo, S. (2012). Promosi Kesehatan dan Ilmu Perilaku. Jakarta : Rineka Cipta

Potter \& Perry,(2010). Fundamental Keperawatan edisi 7. Jakarta: Salemba Medika

Purnama, SG, Susanna, D. (2020). Hygiene and Sanitation Challenge for COVID-19 Prevention in Indonesia. Jurnal Kesehatan Masyarakat Nasional (National Public Health Journal p-ISSN: 1907-7505, e-ISSN: 2460-0601,. http://journal.fkm.ui.ac.id/kesmas

Satgas Covid-19. (2020). Protokol Kesehatan. https://covid19.go.id/p/protokol.
Smeltzer, S.C. \& Bare, B.G.(2010). Brunner and Suddarth Text Book of Medical Surgical Nursing. (8th Ed). Lippincott, Philadelphia.

UNESCO. (2020). Education emergencies. Retrieved March 28, 2020 from

https:/en.unesco.org/themes/educationemergencies/coronavirus-school-closures

Whitehead, D. (2010). Health Promotion in Nursing : a Derridean Discourse Analysis . Health Promotion International, Vol. 26 No 1, 3 Desember 2010. doi: 10.1093/heapro/daq073

WHO. (2020). Corona virus. https://www.who.int/healthtopics/coronavirus\#tab=tab_1

World Health Organization. Coronavirus disease 2019 (COVID-19) Situation Report - 70 [Internet]. WHO; 2020 [updated 2020 March 30; cited 2020 March 31]. Available from: https://www.who.int/ docs/default-source/coronaviruse/situation-rports/20200330- sitrep-70-covid19.pdf?sfvrsn=7e0fe3f8_2

World Health Organization. Naming the coronavirus disease (COVID-19) and the virus that causes it. Geneva: World Health Organization; 2020 [cited 2020 March 29]. Available from: https://www.who.int/emergencies/diseases/novelcoronavirus-2019/technical-guidance/naming-thecoronavirus-disease-(covid-2019)-and-the-virusthat-causes-it

World Health Organization. Situation Report - 42 [Internet]. 2020 [updated 2020 March 02; cited 2020 March 15]. Available from:

https://www.who.int/docs/default-source/ coronaviruse/situation-reports/20200302-sitrep-42covid-19. pdf?sfvrsn=224c1add_2

World Health Organization. WHO Director-General's opening remarks at the media briefing on COVID19 - 11 March 2020 [Internet]. 2020 [updated 2020 March 11]. Available from: 
https://www.who.int/dg/speeches/detail/who-

director-general-s-opening-remarks-at-the-media-

briefing-on-covid-19---11- march-2020.

World Health Organization. (2020). Rational use of personal protective equipment (PPE) for coronavirus disease (COVID-19): interim guidance, 19 March 2020. World Health Organization.

https://apps.who.int/iris/handle/10665/331498. License: CC BY-NC-SA 3.0 IGO. 7p. WHO/2019nCoV/IPC PPE_use/2020.2

Wu Z, McGoogan JM. Characteristics of and Important Lessons From the Coronavirus Disease 2019 (COVID-19) Outbreak in China: Summary of a Report of 72314 Cases From the Chinese Center for Disease Control and Prevention. JAMA. 2020; published online February 24.

DOI: $10.1001 /$ jama.2020.2648

Younie S, Mitchell C, Bisson MJ, Crosby S, Kukona A, et al. (2020) Improving young children's handwashing behaviour and understanding of germs: The impact of A Germ's Journey educational resources in schools and public spaces. PLOS ONE 15(11): e0242134. https://doi.org/10.1371/journal.pone.024 2134

Cite this article as: Utama, J. E. P., Fauzia, W., Jamaludin, M (2021). Edukasi Penerapan Protokol Kesehatan Sebagai Upaya Pencegahan Penyebaran Covid-19 Pada Penderita Komorbid. Jurnal Ilmiah Media Husada. 10(1),34-41. https://doi.org/10.33475/jikmh.v7i2.21 